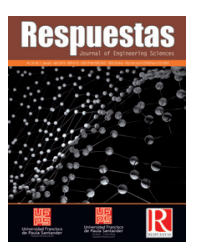

Original Article

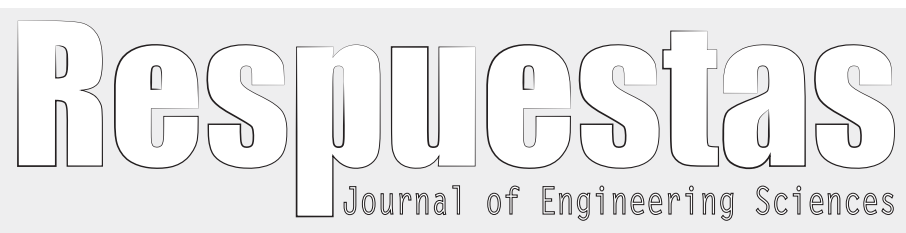

https://doi.org/10.22463/0122820X.1743

\title{
Evaluation of SCS - unit hydrograph model to estimate peak flows in watersheds of Norte de Santander
}

\author{
Evaluación del modelo de hidrograma unitario SCS en la determinación de caudales máximos en cuencas de \\ Norte de Santander
}

\author{
Leonardo Vargas-Garay ${ }^{1}$, Oscar David Torres-Goyeneche ${ }^{2}$, Gustavo Adolfo Carrillo-Soto ${ }^{3 *}$ \\ IIngeniero Civil, leonardovg@ufps.edu.co, ORCID: 0000-0003-4782-8975, Universidad Francisco de Paula Santander, Cúcuta, Colombia. \\ ${ }^{2}$ Ingeniero Civil, oscardavidtg@ufps.edu.co, ORCID: 0000-0003-4593-1987, Universidad Francisco de Paula Santander, Cúcuta, Colombia. \\ 3*Doctor en Hidrología, gustavocarrillo@ufps.edu.co, ORCID: 0000-0001-6772-4431, Universidad Francisco de Paula Santander, Cúcuta, Colombia.
}

How to cite: L. Vargas-Garay, O. Torres-Goyeneche y G. Carrillo-Soto, "Evaluation of SCS - unit hydrograph model to estimate peak flows in watersheds of Norte de Santander", Respuestas, vol. 24, no. 1, pp. 6-16, 2019.

Received on August 10, 2018; Approved on November 15, 2018.

\begin{tabular}{|c|c|}
\hline & ABSTRACT \\
\hline $\begin{array}{l}\text { Keywords: } \\
\text { Peak flows } \\
\text { Unit Hydrograph } \\
\text { Synthetic } \\
\text { Hydrology } \\
\text { SCS }\end{array}$ & $\begin{array}{l}\text { In several studies it is necessary to determine the magnitude of extreme flows in a river. Having an adequate } \\
\text { register of observed discharge, it is possible to adjust a probability density function (fdp) that allows estimating } \\
\text { events associated with a high return period (i.e. } 100 \text { years). In ungauged watersheds, such as the majority } \\
\text { of watersheds in the world are, other methodologies are used, such as the Synthetic Unity Hydrograph } \\
\text { proposed by the United State Soil Conservation Service (UH-SCS). The UH-SCS model was evaluated } \\
\text { in watersheds of the Norte de Santander department (COL), in its capacity to estimate extreme flows, and } \\
\text { to explore its possible regionalization. The evaluation is done by comparing estimates of Q100, using the } \\
\text { Frequency Factors method and the UH-SCS model. Discharge and precipitation time series were obtained } \\
\text { from the IDEAM network, selecting } 19 \text { watersheds based on their drainage area, climatological stations } \\
\text { density and records length. Geomorphology was characterized using ArcMapTM on the ASTER-GDEM } \\
\text { digital elevation model. Using information available on geology, soils, vegetation cover, and assuming a wet } \\
\text { antecedent moisture condition (AMC-III), values of the median of relative Q100 error ( } \varepsilon \text {-Q100) of + 507\% } \\
\text { and + } 406 \% \text { were obtained for the fdp Gumbel and Log-Pearson. Using dry antecedent moisture condition } \\
\text { (AMC-I) } \varepsilon-Q 100 \text { low to + } 36 \% \text { and + 17\%. It was possible to minimize } \varepsilon \text {-Q100 by calibrating the Curve } \\
\text { Number (CN) parameter. A satisfactory regionalization function for CN was not found. Applying SCS-HU } \\
\text { under AMC-III condition, Q100 is greatly overestimated. It is possible to minimize the error by considering } \\
\text { AMC-I and reduce CN, a counter-intuitive situation since extreme flows are associated with wet weather } \\
\text { conditions (i.e. Año Niña). Improvements in the characterization of rainfall and soils in Norte de Santander } \\
\text { should be investigated. }\end{array}$ \\
\hline
\end{tabular}

\section{RESUMEN}

\section{Palabras clave:}

Caudales máximos

Hidrograma

Unitario

Sintético

Hidrología

SCS
En diversos estudios es necesario determinar la magnitud de caudales extremos en un río. Disponiendo de un adecuado registro histórico de caudales es posible ajustar una función de densidad de probabilidad (fdp) que permita estimar eventos asociados con un alto periodo de retorno (i.e. 100 años). En cuencas no-instrumentadas, como son la mayoría de cuencas en el mundo, se recurre a otras metodologías como por ejemplo el Hidrograma Unitario Sintético propuesto por el Servicio de Conservación de Suelos - USA (HU-SCS). Se evaluó el modelo HU-SCS en cuencas del departamento Norte de Santander (COL), en su capacidad para estimar caudales extremos, y explorar su posible regionalización. La evaluación se realiza mediante la comparación de estimaciones de Q100, mediante el método de Factores de Frecuencia y el modelo HU-SCS. Series temporales de caudal y precipitación se obtuvieron de la red IDEAM, seleccionando

*Corresponding author.

E-mail address: gustavocarrillo@ufps.edu.co (Gustavo Adolfo Carrillo Soto)

(c) $(1) \Theta$ Peer review is the responsibility of the Universidad Francisco de Paula Santander.

cc) This is an article under the license CC BY-ND (http://creativecommons.org/licenses/by-nc-nd/4.0/). 
19 cuencas en función de su área de drenaje, densidad de estaciones climatológicas y longitud del registro, caracterizadas geomorfológicamente utilizando ArcMap ${ }^{\mathrm{TM}}$ sobre el modelo digital de elevación ASTERGDEM. Utilizando información disponible sobre geología, suelos, cobertura vegetal, y asumiendo una condición antecedente de suelo húmeda (AMC-III) se obtuvieron valores de la mediana del error relativo Q100 ( $\varepsilon-Q 100)$ de $+507 \%$ y $+406 \%$, para las fdp Gumbel y Log-Pearson. Para una condición antecedente de suelo seca (AMC-I) $\varepsilon$-Q100 bajo a $+36 \%$ y $+17 \%$. Fue posible minimizar $\varepsilon-Q 100$ mediante calibración del parámetro Número de Curva $(\mathrm{CN})$. No se encontró una función de regionalización satisfactoria para $\mathrm{CN}$. Aplicando SCS-HU para condición AMC-III se sobreestima en gran medida el Q100. Es posible minimizar el error al considerar AMC-I y reducir CN, situación contra-intuitiva pues caudales extremos se asocian con condiciones meteorológicas húmedas (i.e. Año Niña). Se debe investigar mejoras en la caracterización de la lluvia y suelos en Norte de Santander.

\section{Introduction}

Water resources management is essential for the planning and sustainable management of the environment in a country like Colombia that has a high biodiversity in much of its geographical extension. The study and knowledge of hydrology, therefore, plays an important role for the identification of water reserves, the determination of demands and supplies of drinking water and to guarantee its quality, as well as the protection of its sources, and specifically for predicting the occurrence of extreme frequency phenomena (increasing and drought).

A hydrological study addresses the problem of a region through a basin, because it represents the physical unit of the area and where the entrance is a precipitation event and the exit is a surface runoff, in this process factors of great importance take influence such as vegetation cover, soil type, area and topography of the area under study. In the process of designing hydraulic works and road infrastructure, a fundamental requirement is the determination of the magnitude of hydrological events that may occur with certain frequency for extreme or maximum values during a given period, for example: The Q100, which corresponds at maximum flow for a return period of one hundred years, and is the most widely used in hydrological design.

However, by not having historical flow data in most of the country's river watersheds (Non-Instrumented Watersheds), these flows can be deduced through hydrological models, which have been developed, through empirical formulation, referred to as synthetic unit hydrographs, which estimate surface runoff based on the morphometric characteristics of the watersheds under study. Basically these models consist of the relationship of the parameters of the method, with the hydrological processes that occur in the basin; These models have been calibrated in the geography of the countries where they were developed, to establish their parameters, for this reason there is uncertainty in the application of these hydrological models in the region, because the values of the parameters are chosen subjectively.

\section{Materials and methods}

\section{Information used}

The information used is made up of the historical series of annual maximum flows for 19 stations with at least 19 years of registration and precipitation data in the representative stations of the study area in the department of Norte de Santander, obtained through the process of requesting hydrometeorological parameters from the IDEAM database. In addition, the ASTER GDEM digital elevation model (ASTER Global Digital Elevation Model) was used for the morphological characterization of the watersheds. The characterization of the watersheds was made from the basic cartography prepared by the IGAC in geodatabase format. Information on land cover and land use was also required, for which IDEAM obtained the land cover map, scale 1: 100,000 , according to the CORINE methodology (Coordination of Information on the Environmental) Land Cover adapted for Colombia [1]. And the General Survey of soils and land zoning of the North department of Santander prepared by the IGAC, this publication consists of a technical report and a 1 : 100,000 scale map of the cartographic units of soils [2]. 


\section{Methodology}

IInitially, the morphometric characterization of the selected watersheds was carried out, through the use of geo-processing tools in $\operatorname{ArcGIS}^{\circledR}$ software. Table I presents the most important information of the Ideam stations and the geomorphological characteristics of each of the watersheds. From the criterion of drainage area less than $1000 \mathrm{~km}^{2}$, the application of the HU-SCS was carried out, considering it as a prudent range to use this model, noting also that the Soil Conservation Service does not establish a restriction as to the area limit of drainage of a basin for the application of the method. Figure I shows the location and spatial distribution of the watersheds studied. the hydrological record can significantly affect the statistical parameters calculated for the information, the rising peaks considered as high questionable data were compared with the historical information of floods in nearby stations, and having given that nearby sites have similar trends in their information, unusual extreme peaks were removed from the analysis.

An equation is proposed to estimate maximum events related to a given return period $\mathrm{T}$. The equation relates the statistical parameters, mean and standard deviation of the data available in the historical record, and a frequency factor, $K T$, related to a specific return period and the probability distribution used. The equation is expressed as follows: $X T=\bar{X}+K T \sigma$;

Table I. Information on seasons and morphometric characteristics of basins

\begin{tabular}{|c|c|c|c|c|c|c|c|c|c|c|}
\hline \multirow{2}{*}{ Ideam Station } & \multirow{2}{*}{ Code } & \multirow{2}{*}{ Current } & \multirow{2}{*}{$\begin{array}{c}\text { Height } \\
{[\mathrm{msnm}]}\end{array}$} & \multirow{2}{*}{$\begin{array}{l}\text { Registration } \\
\text { Period }\end{array}$} & \multirow{2}{*}{$\begin{array}{c}\text { Num. Years } \\
\text { of } \\
\text { Registration }\end{array}$} & $\mathbf{A}$ & $\mathbf{Y}$ & $l$ & $\mathbf{L}$ & $\mathbf{S}$ \\
\hline & & & & & & {$\left[\mathbf{K m}^{2}\right]$} & {$[\%]$} & {$[\mathrm{Km}]$} & {$[\mathrm{Km}]$} & {$[\mathbf{m} / \mathbf{m}]$} \\
\hline El Campanario & 16057060 & Qda Campanario & 1440 & $1979-2001$ & 21 & 21.45 & 33.7 & 9.86 & 7.33 & 0.10 \\
\hline La Cabrera & 16057070 & Qda El Molino & 1400 & $1979-2001$ & 22 & 24.69 & 43.0 & 16.66 & 13.72 & 0.14 \\
\hline La Soledad & 16057050 & Qda La Soledad & 1460 & $1979-2001$ & 21 & 27.00 & 28.2 & 11.85 & 9.27 & 0.15 \\
\hline Berlín & 37017010 & Jordán & 3330 & $1972-2000$ & 27 & 48.63 & 20.8 & 16.15 & 10.52 & 0.04 \\
\hline Las Vegas & 16057010 & Frio & 1420 & $1972-2014$ & 38 & 69.84 & 36.1 & 21.63 & 16.82 & 0.14 \\
\hline Los Pomarrosos & 16027010 & Salazar & 850 & $1988-2014$ & 26 & 101.00 & 67.2 & 24.07 & 17.76 & 0.20 \\
\hline Marcelita & 16057020 & Oroque & 1380 & $1972-2006$ & 35 & 105.76 & 31.5 & 29.38 & 23.15 & 0.17 \\
\hline Campo Seis & 16037040 & Tibú & 70 & $1973-2014$ & 41 & 314.60 & 36.0 & 37.29 & 25.70 & 0.12 \\
\hline Pte Abrego & 16047010 & Tarra & 1430 & $1971-2014$ & 44 & 367.35 & 40.7 & 40.34 & 28.91 & 0.08 \\
\hline Pte Capira & 16027300 & Zulia & 1320 & $2004-2015$ & 12 & 391.57 & 45.8 & 53.38 & 33.06 & 0.14 \\
\hline Pte San Miguel & 16037050 & San Miguel & 75 & $1984-2014$ & 31 & 410.52 & 19.9 & 48.83 & 38.58 & 0.05 \\
\hline La Donjuana & 16017020 & Pamplonita & 730 & $1973-2014$ & 42 & 422.69 & 45.3 & 53.35 & 38.84 & 0.09 \\
\hline Cornejo & 16027100 & Peralonso & 270 & $1969-2014$ & 45 & 460.80 & 45.8 & 61.18 & 51.48 & 0.12 \\
\hline La Cabaña & 16057030 & Algodonal & 1220 & $1971-2014$ & 44 & 530.78 & 31.1 & 57.23 & 39.40 & 0.06 \\
\hline El Hoyo & 23197410 & San Alberto & 77 & $1974-2015$ & 39 & 604.11 & 36.0 & 68.36 & 56.53 & 0.06 \\
\hline Campo Tres & 16037010 & Nuevo Presidente & 50 & $1972-2014$ & 43 & 706.20 & 34.8 & 64.77 & 56.50 & 0.08 \\
\hline El Cincho & 16047030 & Tarra & 1090 & 1981-1999 & 19 & 722.07 & 43.2 & 72.35 & 60.45 & 0.27 \\
\hline Pte López & 37017040 & Chitagá & 1862 & $1973-2014$ & 42 & 834.05 & 38.1 & 58.36 & 42.58 & 0.15 \\
\hline Pte Sardinata & 16037030 & Sardinata & 245 & $1973-2014$ & 42 & 909.88 & 50.6 & 67.08 & 58.19 & 0.13 \\
\hline
\end{tabular}

\section{Frequency analysis}

To each historical series of annual maximum flows, the test of doubtful data (Outliers) recommended by the Water Resources Council [3] was applied, which consists of identifying, through hydrological and mathematical criteria, points of information that depart from the trend of the remaining information. Because the inclusion or exclusion of these data in where $X T$ is the magnitude of the maximum event to calculate, $\bar{X}$ the arithmetic mean of the sample, $\sigma$ standard deviation, y $K T$ the frequency factor.

For each selected station, the maximum flow rate for a one hundred year return period (Q100) was determined, using the frequency factors as distributions of maximum values: Gumbel and LogPearson Type III. 


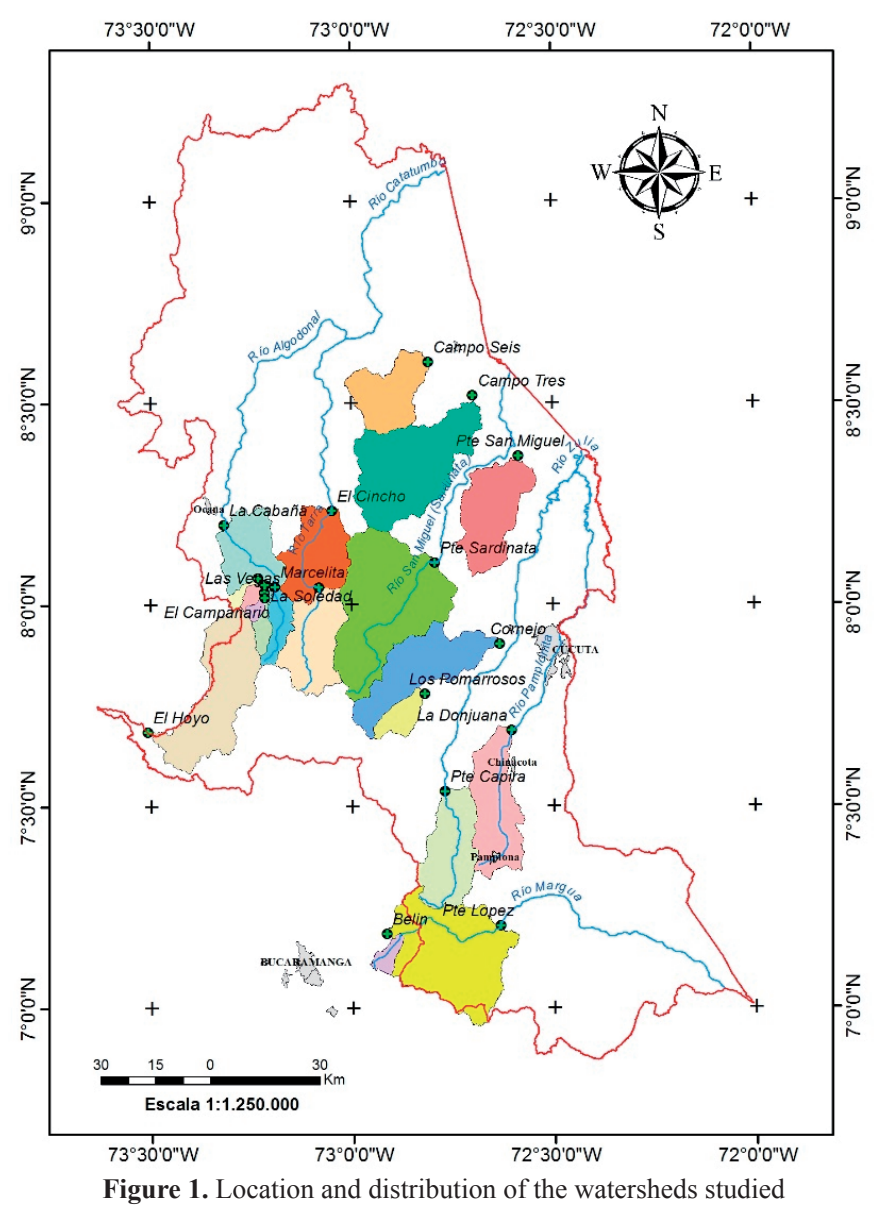

Estimation of the curve number, $\mathrm{CN}$

The runoff curve $(\mathrm{CN})$ number was obtained for the three background humidity conditions in each basin, based on the land cover and land use maps, and through the use of geo-processing tools in ArcGIS ${ }^{\circledR}$ and ArcMap ${ }^{\mathrm{TM}}$ software by Esri. Using the tables of values of the $\mathrm{CN}$ curve number proposed by [4] in which a correspondence is established with the land uses indicated in the CORINE Land-Cover (CLC) project. A relationship with the soil mapping units defined by the IGAC is proposed for the definition of the soil hydrological group, based on the relationship of the soil texture of the United States Department of Agriculture (USDA) with the hydrological groups that establish Brakensiek and Rawls (1983), which has even been admitted by the reference body for the runoff curve number (Soil Conservation Service) as mentioned in [5], and also taking into account the depth of the most impermeable layer of the edaphic profile representative of each soil unit. Table III presents an extract of the definition of hydrological groups according to the soil mapping units. Table IV shows the curve number values for the three background humidity conditions (AMC) defined by the Soil Conservation Service, in each of the watersheds.

\section{SCS synthetic unit hydrograph}

The unit hydrograph for an effective rainfall of 1 $\mathrm{mm}$ was obtained for each basin, using the method developed by the Soil Conservation Service [6]. The soil conservation service of the United States (SCS), currently NRCS (National Resources Conservation Service), empirically developed a dimensionless unit hydrograph, and corresponds to the end product of this important field of research and work of numerous researchers. This hydrological model was established based on the analysis of a series of natural unit hydrographs belonging to watersheds of a wide range of sizes and located in different parts of the United States geography, as described in [6].

For an effective millimeter of rainfall, in the metric system, the peak flow is equal to:

$$
Q_{p}=0.208^{*} A / T_{p}
$$

Where:

$Q_{p}$ is the peak flow $\left(\mathrm{m}^{3} / \mathrm{s}\right)$

$A$ is the drainage area of the basin $\left(\mathrm{km}_{2}\right)$

$T_{p}$ is the time at the peak of the triangular hydrograph (h)

To estimate the peak time the Soil Conservation Service establishes the following relationship with the delay time of the basin: $T_{p}=(10 / 9) T_{r}$

The curve number $(\mathrm{CN})$ method expresses the delay time of the basin through the following equation:

$$
\begin{gathered}
T_{r}=\left[^{0.8}[2540-22.86 C N]^{0.7}\right] \\
14104 C N^{0.7} y^{0.5}
\end{gathered}
$$

Equation (2) is restricted to $\mathrm{CN}$ curve numbers in a range of 50 to 95 .

\section{Precipitation Hietograms}

Rain intensities for a return period of one hundred years were determined using the regionalized 


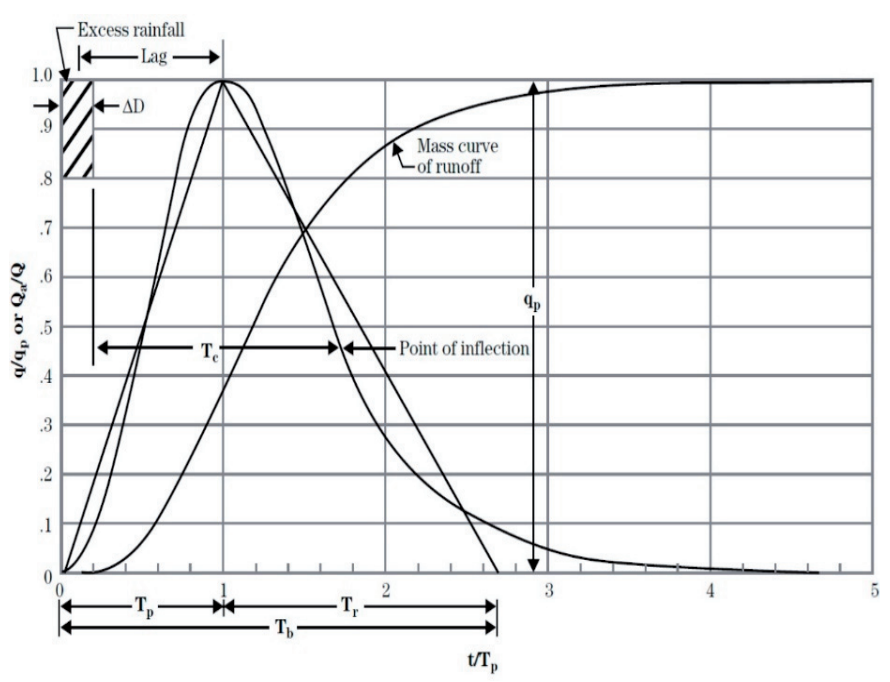

Figure 2. Dimensional unit hydrograph of the SCS Source: [6]

intensity-duration-frequency synthetic curves method for Colombia, proposed by [7] and adopted by INVÍAS in [8], in which they establish a correlation with the maximum annual average rainfall in 24 hours. In this way the precipitation hietograms were determined by the alternate block method. Additionally, the reduction of rainfall by spatiality was carried out using the factor proposed by the RAS in [9], as a relationship with the drainage area, for which the Equation was defined: $\mathrm{f}(\mathrm{a})=$ $-0.039 \ln (\mathrm{A})+1.1522$, where $\mathrm{A}$ is the drainage area in square meters $\left(\mathrm{m}^{2}\right)$, adjusting a Logarithmic trend line with a $\mathrm{R}^{2}$ coefficient of determination of 0.9851 .

$$
i=a T^{b} M^{d}
$$

$$
(t / 60)^{c}
$$

\section{Where:}

$i$ is the intensity of precipitation $(\mathrm{mm} / \mathrm{h})$

$T$ is the return period (years)

$M$ is the maximum annual average rainfall in $24 \mathrm{~h}$ at the multi-year level ( $\mathrm{mm}$ )

$t$ is the duration of the rain (min)

$a, b, c, d$ is the regression adjustment parameters (-)

Precipitation abstractions and their temporal distribution to define effective rainfall hietograms were calculated using the curve number method (USDS. SCS Curve Number Runoff).
Table II. Values of the coefficients a, b, c y d

\begin{tabular}{|c|c|c|c|c|}
\hline REGIÓN & a & b & c & d \\
\hline Andina (R1) & 0.94 & 0.18 & 0.66 & 0.83 \\
\hline Caribe (R2) & 24.85 & 0.22 & 0.50 & 0.10 \\
\hline Pacífico (R3) & 13.92 & 0.19 & 0.58 & 0.20 \\
\hline Orinoquía (R4) & 5.53 & 0.17 & 0.63 & 0.42 \\
\hline \multicolumn{5}{|c|}{ Source: [7] }
\end{tabular}

In Figure 3: Ia is the initial abstraction, $\mathrm{Pe}$ is the excess rainfall, $\mathrm{Fa}$ is the continuous abstraction, $\mathrm{P}$ is the total precipitation, $\mathrm{S}$ is the maximum potential retention and $\mathrm{CN}$ is the runoff curve number.

By means of the linearity principle, the Convolution of the unit hydrograph was carried out to obtain the maximum flows of direct runoff, the contribution of the base flow for the estimation of the maximum flows was not taken into account, taking into account that for extreme peaks of increasing the percentage base flow is not significant compared to the total flow.

The relative errors of the model were calculated with the results of the frequency analysis.



Figure 3. Variables in the method of precipitation abstractions of the SCS. Source: [3]

The goodness of the fit of the model was quantitatively evaluated using the root of the mean square error (RMSE) and the root of the mean square quadratic error (RMSEP).

\section{Model parameter setting}

The optimum NC curve numbers, that is, the optimized values of this parameter for which the 
maximum flow calculated by means of the synthetic unit hydrograph of the SCS accurately predicted the maximum flow obtained by means of the test-error calibration, were determined the frequency factor of the Log-Pearson distribution. Subsequently, a regionalization analysis of the optimal curve number parameter was performed, based on the fundamental concept of hydrological homogeneity in a region. The study watersheds were divided considering ranges of $\mathrm{CN}$ values and their topographic and climatic characteristics were evaluated.

\section{Results and Discussions}

Table $\mathrm{V}$ and Figure 4 show the maximum flows for a return period of 100 years calculated using the SCS synthetic unit hydrograph method, for the three antecedent humidity conditions (AMC) established in the model. The relative errors are also shown, comparing these results with the maximum flows using the frequency factors.

When the maximum flows calculated by the synthetic unit hydrograph of the SCS are compared with those obtained using the frequency factors; Considering that for maximum flood events the use of the antecedent moisture condition with wet soil (AMC

Table III. Hydrological groups in function of the soil units of Norte de Santander

\begin{tabular}{|c|c|c|c|c|c|c|}
\hline No & U.C.S. & TAXONOMIC COMPONENT & \% & SOIL TEXTURE & DEPTH & HSG \\
\hline 1 & MEAg & Afloramientos Rocosos - Lithic Cryumbrepts & 100 & Clay loam & Very shallow limited by rock & D \\
\hline 2 & MHDa & Typic Fluvaquents & 70 & Loam & Very superficial to superficial & B \\
\hline 3 & MJAg & Lithic Tropofolists - Afloramientos Rocosos & 90 & Sandy loam & Very shallow limited by rock & D \\
\hline 4 & MJBe & Typic Dystropepts - Afloramientos Rocosos & 100 & Clay & Surface & D \\
\hline 5 & MKBf & Typic Humitropepts & 90 & Sandy loam & Deep & A \\
\hline 6 & MKDf & Typic Dystropepts - Typic Humitropepts & 100 & Sandy clay loam & Deep \\
\hline
\end{tabular}

Table IV. SCS number values of SCS

\begin{tabular}{|c|c|c|c|c|}
\hline \multicolumn{2}{|c|}{ Watersheds } & \multicolumn{3}{c|}{ Curve Number, CN } \\
\hline No & Hydrological Station & AMC I & AMC II & AMC III \\
\hline 1 & El Campanario & 57 & 76 & 88 \\
\hline 2 & La Cabrera & 51 & 70 & 84 \\
\hline 3 & La Soledad & 64 & 81 & 91 \\
\hline 4 & Berlín & 66 & 83 & 93 \\
\hline 5 & Las Vegas & 55 & 75 & 87 \\
\hline 6 & Los Pomarrosos & 53 & 73 & 86 \\
\hline 7 & Marcelita & 62 & 79 & 90 \\
\hline 8 & Campo Seis & 52 & 71 & 85 \\
\hline 9 & Pte Abrego & 58 & 77 & 88 \\
\hline 10 & Pte Capira & 59 & 77 & 89 \\
\hline 11 & Pte San Miguel & 50 & 69 & 83 \\
\hline 12 & La Donjuana & 57 & 76 & 88 \\
\hline 13 & Cornejo & 57 & 75 & 88 \\
\hline 14 & La Cabaña & 62 & 79 & 90 \\
\hline 15 & El Hoyo & 55 & 74 & 87 \\
\hline 16 & Campo Tres & 50 & 68 & 82 \\
\hline 17 & El Cincho & 62 & 80 & 90 \\
\hline 18 & Pte López & 66 & 82 & 92 \\
\hline 19 & Pte Sardinata & 52 & 72 & 85 \\
\hline
\end{tabular}

III) is recommended, it is observed that the relative errors in most of the watersheds are much greater than $100 \%$, that is, the flows maximums calculated for the recurrence period are greatly overestimated. When calculating the maximum flows for the antecedent condition of medium humidity (AMC II), logically the relative errors decrease, but the differences in the flows remain considerably high for most of the watersheds, except in four, where the relative errors are under $65 \%$. Finally, when estimating the maximum flow rates for the antecedent condition of humidity with dry soil (AMC I), it is observed that for most of the watersheds; excluding the four mentioned above, the relative errors are less than $66 \%$.

It is observed that the results for the antecedent moisture condition AMC III, CN values greater than 80 , report very high differences with respect to the frequency factors, with relative errors up to $1000 \%$ or greater.

The methodology of synthetic unit hydrographs is 
widely used in Colombia, there are investigations where similar errors are reported, such as the investigations carried out by [10] in the Faculty of Mines, Universidad Nacional de Colombia, Medellin Headquarters, for a set of watersheds, which report very different results with the different models of synthetic unit hydrographs (among them the one developed by the SCS) for the same basin, with differences of up to $1000 \%$ in the estimates. Also, there is the research carried out by [11] in which the results obtained for maximum flows with different return periods estimated by different methods are presented, of which the frequency analyzes and the synthetic unit hydrograph of the SCS are highlighted, in three watersheds of Antioquia and the Coffee Axis, in this sense, the overestimation of the results is reported using the SCS synthetic unit hydrograph with respect to the frequency analysis (Log Normal and Gumbel), with errors that ranged between 111 and $274 \%$.

In summary, the greatest approximation in the estimates was obtained for most of the basins using the curve number for the previous AMC I moisture condition, except for the basins: Las Vegas, Los Pomarrosos, Marcelita y Campo Seis, where the greatest approximation was obtained using the curve number for the antecedent moisture condition AMC II, for these basins there is the highest standard deviation in relation to the average of the flows, that is to say high variability in the annual maximum flows, such as It can be seen in Table 3. This situation can be explained by various causes, the main ones being: annual rainfall greater than $1600 \mathrm{~mm}$, average slope of the main channel between 12 and 20\%, and moderate to excessive water yields ranging from 26 and $82 \mathrm{l} / \mathrm{s} / \mathrm{km}^{2}$, pointing out that they are watersheds with areas between 70 and $315 \mathrm{~km}^{2}$.

Taking into account what has been mentioned above about the greater approximation of the results, the goodness of the estimates was quantitatively determined, evaluating the root of the mean square error (RMSE) and the root of the mean square

Table V. Maximum flows for a return period of 100 years, values in $\mathrm{m}^{3} / \mathrm{s}$

\begin{tabular}{|c|c|c|c|c|c|c|c|c|c|c|c|c|}
\hline \multirow{2}{*}{\multicolumn{2}{|c|}{ Watersheds }} & \multicolumn{2}{|c|}{ Frequency Factors } & \multirow{2}{*}{\multicolumn{3}{|c|}{ SCS synthetic unit hydrograph }} & \multicolumn{6}{|c|}{ Relative Errors [\%] } \\
\hline & & \multirow{3}{*}{$\begin{array}{c}\text { Gumbel } \\
Q_{100} \\
{\left[\mathrm{~m}^{3} / \mathbf{s}\right]}\end{array}$} & \multirow{3}{*}{$\begin{array}{c}\text { Log-Pearson } \\
Q_{100} \\
{\left[\mathrm{~m}^{3} / \mathrm{s}\right]}\end{array}$} & & & & & Gumbel & & & g-Pear & \\
\hline \multirow{2}{*}{ No } & \multirow{2}{*}{$\begin{array}{c}\text { Hydrological } \\
\text { Station }\end{array}$} & & & \multirow{2}{*}{ AMC III } & \multirow{2}{*}{ AMC II } & \multirow{2}{*}{ AMC I } & \multirow{2}{*}{$\begin{array}{c}\text { AMC } \\
\text { III }\end{array}$} & \multirow{2}{*}{$\begin{array}{c}\text { AMC } \\
\text { II }\end{array}$} & \multirow{2}{*}{$\underset{\text { I }}{\text { AMC }}$} & \multirow{2}{*}{$\begin{array}{c}\text { AMC } \\
\text { III }\end{array}$} & \multirow{2}{*}{$\begin{array}{c}\text { AMC } \\
\text { II }\end{array}$} & \multirow{2}{*}{$\begin{array}{c}\mathbf{A M C} \\
\mathbf{I}\end{array}$} \\
\hline & & & & & & & & & & & & \\
\hline 1 & El Campanario & 18.15 & 28.60 & 254.96 & 131.26 & 47.42 & 1305 & 623 & 161 & 791 & 359 & 66 \\
\hline 2 & La Cabrera & 16.53 & 15.41 & 158.94 & 66.91 & 17.60 & 862 & 305 & 6 & 932 & 334 & 14 \\
\hline 3 & La Soledad & 18.89 & 25.60 & 335.92 & 176.34 & 75.21 & 1678 & 833 & 298 & 1212 & 589 & 194 \\
\hline 4 & Berlín & 16.98 & 13.73 & 144.30 & 103.58 & 27.77 & 750 & 510 & 64 & 951 & 654 & 102 \\
\hline 5 & Las Vegas & 205.54 & 342.97 & 602.05 & 325.94 & 115.56 & 193 & 59 & -44 & 76 & -5 & -66 \\
\hline 6 & Los Pomarrosos & 243.88 & 491.38 & 1389.11 & 812.02 & 332.20 & 470 & 233 & 36 & 183 & 65 & -32 \\
\hline 7 & Marcelita & 234.25 & 284.31 & 712.70 & 403.52 & 163.23 & 204 & 72 & -30 & 151 & 42 & -43 \\
\hline 8 & Campo Seis & 1446.32 & 1600.85 & 2977.15 & 1795.21 & 821.98 & 106 & 24 & -43 & 86 & 12 & -49 \\
\hline 9 & Pte Abrego & 283.61 & 260.92 & 1956.72 & 1104.83 & 405.64 & 590 & 290 & 43 & 650 & 323 & 55 \\
\hline 10 & Pte Capira & 138.23 & 163.52 & 1618.92 & 855.16 & 302.12 & 1071 & 519 & 119 & 890 & 423 & 85 \\
\hline 11 & Pte San Miguel & 604.44 & 650.24 & 2335.94 & 1419.13 & 665.33 & 286 & 135 & 10 & 259 & 118 & 2 \\
\hline 12 & La Donjuana & 227.96 & 247.22 & 1719.08 & 919.49 & 339.63 & 654 & 303 & 49 & 595 & 272 & 37 \\
\hline 13 & Cornejo & 717.77 & 879.41 & 3033.10 & 1705.60 & 872.44 & 323 & 138 & 22 & 245 & 94 & -1 \\
\hline 14 & La Cabaña & 445.45 & 510.95 & 2305.76 & 1308.07 & 630.22 & 418 & 194 & 41 & 351 & 156 & 23 \\
\hline 15 & El Hoyo & 211.49 & 190.47 & 3981.17 & 2375.38 & 1140.67 & 1782 & 1023 & 439 & 1990 & 1147 & 499 \\
\hline 16 & Campo Tres & 1343.65 & 1297.24 & 4278.99 & 2408.79 & 1353.71 & 218 & 79 & 1 & 230 & 86 & 4 \\
\hline 17 & El Cincho & 242.82 & 231.75 & 3028.91 & 1743.89 & 758.53 & 1147 & 618 & 212 & 1207 & 652 & 227 \\
\hline 18 & Pte López & 409.02 & 473.79 & 2482.53 & 1283.85 & 481.39 & 507 & 214 & 18 & 424 & 171 & 2 \\
\hline 19 & Pte Sardinata & 697.81 & 714.09 & 3926.93 & 2078.63 & 836.49 & 463 & 198 & 20 & 450 & 191 & 17 \\
\hline
\end{tabular}






Figure 4. Maximum flows for a return period of 100 years, values in $\mathrm{m}^{3} / \mathrm{s}$

quadratic error (RMSEP), an RMSE was obtained $=273$ and an RMSEP $=140 \%$. Excluding the two basins with records under 20 years (Pte Capira and El Cincho) and the basin with the highest relative error (El Hoyo), an RMSE $=117$ and an RMSEP $=$ $63 \%$ are obtained.

It can also be seen from Table $\mathrm{V}$ that the greatest errors occur in the basins: El Hoyo and El Cincho, from the latter it can be noted that the historical series of flows is less than 20 years, and it is likely that it is not significant to represent the maximum flow rate for a high recurrence period. El Hoyo watershed It has particular conditions, it is an area of high rainfall; with an annual precipitation of $2170 \mathrm{~mm}$ and with maximum annual average precipitation in 24 hours of $112 \mathrm{~mm}$, it is also an area with excessive water performance values, an average of $531 / \mathrm{s} / \mathrm{km}^{2}$, but even with these conditions the historical series of maximum flows corresponding to 39 years of registration does not show considerably high flows, as can be seen in Table 3, the mean and standard deviation of the flows do not seem to describe the extreme climatic conditions of this area, as happens for example in the Campo trees basin that has similar conditions. This situation could be explained mainly by two causes, the first is that it could be due to a geological condition in the area near the discharge point or measurement site, the second reason could be due to the anthropic action, caused by surface uptakes, also pointing out which is a dense crop area.

\section{Parameter setting}

From the conditions that presented the smallest errors in the estimates, the calibration procedure was carried out by Test - error, determining the optimal $\mathrm{CN}$ curve numbers, for which the maximum flow rate calculated by the synthetic unit hydrograph of the SCS predicted Exact the maximum flow rate obtained by the Log-Pearson frequency factor. The results are shown in table V.

The results of Table VI can be interpreted as follows: the three basins with the smallest drainage area show a practically equal calibrated curve number, this is logical considering that the basins are concentrated in one area; as can be seen in Figure 1, where the climatic conditions are homogeneous. However, the curve numbers calculated for the AMC I condition have large differences from each other, this can be explained taking into account that the scale of the soil units to define the hydrological groups generates a high sensitivity in the $\mathrm{CN}$ values.

In watersheds with drainage areas approximately between 50 and $315 \mathrm{~km}^{2}$ curve numbers of 60 and greater than 70 are observed, they can be explained by the reasons mentioned above referring to the basins where the greatest approximation was reported using the curve number for the AMC II condition, except for the Berlin basin, particularly in this area of the moor, there is the lowest rainfall in the department, evidenced by an average annual maximum rainfall in 24 hours of less than $40 \mathrm{~mm}$.

For watersheds with drainage areas between 365 and $910 \mathrm{~km}^{2}$; excluding the El Hoyo basin, which presents anomalous conditions explained above, and considering the SCS restriction for the delay time equation with curve numbers not less than 50, optimal curve numbers are between 50 and 60 , except for the basin Pte López showing a CN greater than 60 , which can be explained because it is an area with a maximum annual average rainfall in 24 hours less than $40 \mathrm{~mm}$, coinciding with the characteristics of the Berlin basin, which are located in a moor area. 
Table VI. Maximum flows for a return period of 100 years. calibration

\begin{tabular}{|c|c|c|c|c|c|c|c|}
\hline \multirow{2}{*}{\multicolumn{3}{|c|}{ Watersheds }} & \multicolumn{2}{|c|}{ Frequency Factors } & \multirow{4}{*}{$\begin{array}{c}\text { SCS Synthetic HU } \\
\text { Q100 } \\
{\left[\mathrm{m}^{3} / \mathbf{s}\right]}\end{array}$} & \multirow{4}{*}{$\begin{array}{c}\text { Optimum } \\
\mathrm{CN} \\
{[-]}\end{array}$} & \multirow{4}{*}{$\begin{array}{c}\text { Log-Pearson } \\
\text { Relative Error }\end{array}$} \\
\hline & & & Gumbel & Log-Pearson & & & \\
\hline \multirow{2}{*}{ No } & \multirow{2}{*}{ Hydrological Station } & $\mathbf{A}$ & Q100 & Q100 & & & \\
\hline & & {$\left[\mathbf{K m}^{2}\right]$} & {$\left[\mathrm{m}^{3} / \mathbf{s}\right]$} & {$\left[\mathrm{m}^{3} / \mathbf{s}\right]$} & & & \\
\hline 1 & El Campanario & 21.4 & 18.15 & 28.60 & 29.08 & 50 & $1.68 \%$ \\
\hline 2 & La Cabrera & 24.7 & 16.53 & 15.41 & 15.67 & 50 & $1.72 \%$ \\
\hline 3 & La Soledad & 27.0 & 18.89 & 25.60 & 25.82 & 49 & $0.84 \%$ \\
\hline 4 & Berlín & 48.6 & 16.98 & 13.73 & 13.90 & 60 & $1.28 \%$ \\
\hline 5 & Las Vegas & 69.8 & 205.54 & 342.97 & 343.73 & 76 & $0.22 \%$ \\
\hline 6 & Los Pomarrosos & 101.0 & 243.88 & 491.38 & 491.97 & 60 & $0.12 \%$ \\
\hline 7 & Marcelita & 105.8 & 234.25 & 284.31 & 286.24 & 72 & $0.68 \%$ \\
\hline 8 & Campo Seis & 314.6 & 1446.32 & 1600.85 & 1607.88 & 69 & $0.44 \%$ \\
\hline 9 & Pte Abrego & 367.4 & 283.61 & 260.92 & 262.82 & 51 & $0.73 \%$ \\
\hline 10 & Pte Capira & 391.6 & 138.23 & 163.52 & 164.88 & 50 & $0.83 \%$ \\
\hline 11 & Pte San Miguel & 410.5 & 604.44 & 650.24 & 651.26 & 50 & $0.16 \%$ \\
\hline 12 & La Donjuana & 422.7 & 227.96 & 247.22 & 249.52 & 51 & $0.93 \%$ \\
\hline 13 & Cornejo & 460.8 & 717.77 & 879.41 & 884.90 & 57 & $0.62 \%$ \\
\hline 14 & La Cabaña & 530.8 & 445.45 & 510.95 & 513.31 & 58 & $0.46 \%$ \\
\hline 15 & El Hoyo & 604.1 & 211.49 & 190.47 & 232.11 & 30 & $21.86 \%$ \\
\hline 16 & Campo Tres & 706.2 & 1343.65 & 1297.24 & 1314.37 & 50 & $1.32 \%$ \\
\hline 17 & El Cincho & 722.1 & 242.82 & 231.75 & 236.60 & 44 & $2.10 \%$ \\
\hline 18 & Pte López & 834.0 & 409.02 & 473.79 & 474.00 & 66 & $0.05 \%$ \\
\hline 19 & Pte Sardinata & 909.9 & 697.81 & 714.09 & 714.85 & 47 & $0.11 \%$ \\
\hline
\end{tabular}

One of the reasons to understand the overestimations so high that the application of the SCS model generates, can be explained by the generation of precipitation hietograms, due to the lack of rainfall information rainfall intensities were obtained by a synthetic method, this situation increases the uncertainty of the estimates, referring to the research carried out by [12] in Universidad Santo Tomás Tunja, on the regionalization of IDF curves in the department of Boyacá, which presents the comparison with the method of regionalized intensity-durationfrequency synthetic curves for Colombia proposed by [7], reporting that this method exceeds the intensity results associated with a return period of up to $300 \%$.

Finally, a multivariable linear regression analysis with physical characteristics of easily obtainable basins that were related to the parameters that define the $\mathrm{CN}$ was carried out with the purpose of regionalizing the optimal curve numbers, however, a correlation that significantly described was not obtained. The behavior of the optimal $\mathrm{CN}$ curve numbers, according to the coefficient of determination which yielded very low R2 values. Situation that can be explained by various causes, among them, the great diversity of topographic and climatic conditions for which similar optimal $\mathrm{CN}$ values are obtained, and also the high variability of the conditions of the ground-floor complex that define this parameter. It is evidenced in this way that there is no linear relationship between the curve number and the geomorphoclimatic characteristics.

In [13] it is stated: "The regionalization methods based on multivariate linear regressions between the extreme flows and some hydrographic characteristics of the basins, do not point to understanding and ignore the complexity of the nonlinear and emerging phenomena in the hydrological basins" (p.68).

This concept is also valid for the parameters to be calibrated in hydrological models. 


\section{Conclusions}

The results obtained by the synthetic unit hydrograph of the SCS in the calculation of maximum flows are always above those estimated using frequency analysis for a return period of one hundred years with the Gumbel and Log-Pearson distribution. With exaggeratedly greater results using the curve number for the antecedent moisture condition AMC III. This situation is based on the results that in 1981, the Water Resources Council (WRC), cited by Linsley, showed the analysis of several methodologies used in non-instrumented basins, finding that all methods were subject to large errors and they presented a tendency to overestimate flows as cited in [11].

The optimal curve numbers in most of the basins tend to be very close to the $\mathrm{CN}$ values for the previous AMC I moisture condition, which is counterintuitive, considering that normally the maximum floods occur in the strong winter seasons in where the soil has a wet condition.

No correlation was found between the optimal curve numbers and the geomorphoclimatic characteristics of the basins studied, for this reason it was not possible to regionalize the optimal $\mathrm{CN}$ in Norte de Santander.

Given the great uncertainty presented by the SCS unit hydrograph model to estimate maximum flows in the conditions of poor information for the basins in Norte de Santander, the lack of hydrological information of instantaneous flows in the department and in general throughout the country.

For a more reliable use of the synthetic unit hydrograph of the SCS, it is recommended to study in a more detailed way the conditions and parameters that define the curve number and the previous condition of humidity, in this way to have tools that allow to reduce the uncertainty, taking into account that it is the only parameter of the model and the one with the most sensitivity both to determine the flow and time at the peak of the unit hydrograph, and to estimate precipitation abstractions.

In non-instrumented watersheds, the reduction of uncertainty in the basic information used is required, especially in the rain data, being essential and as a recommendation the installation of pluviograph stations in strategically distributed points and in climatologically homogeneous areas, which allow obtaining and interpolation of rainfall intensities, so that reliability in hydrological design and modeling increases.

\section{References}

[1] IDEAM, "Leyenda nacional de coberturas de la tierra. Metodología CORINE Land Cover adaptada para Colombia escala 1:100.000”, 2010. [Online]. Disponible en: http://siatac.co/c/document_library/ get_file?uuid=a64629ad-2dbe-4e1e-a561 fc16b8037522\&groupId $=762$.

[2] IGAC. Estudio general de suelos y zonificación de tierras del departamento Norte de Santander. Bogotá D.C. Instituto Geográfico Agustín Codazzi, 2004.

[3] V. T. Chow, D. Maidment and L. Mays. "Hidrología aplicada. Bogotá D.C", McGrawHill Interamericana, 1994.

[4] J. Ferrer, J. Blanco and J. Ramírez, "Propuesta metodológica para la adaptación del parámetro del número de curva a las nuevas fuentes de datos", 2006. [Online]. Disponible en: http:// www.ciccp.es/ biblio_digital/Icitema_III/ congreso/pdf/040205.pdf

[5] R. Fernández, "Mejora de los parámetros de cálculo del modelo del número de curva y su validación mediante un modelo hidrológico distribuido", 2006. [Online]. Disponible en: http:// rabida.uhu.es/dspace/ handle/10272/2723.

[6] NRCS, "National Engineering Handbook Hydrology Chapters", 2015. [Online]. Disponible en: http://www.nrcs.usda.gov/wps/ portal/nrcs/ detailfull//?cid=stelprdb1043063.

[7] R. Vargas and M. Díaz-Granados. "Curvas sintéticas regionalizadas de intensidadduración-frecuencia para Colombia", Universidad de los Andes, Bogotá, 1998. 
[8] INVÍAS, "Manual de drenaje para carreteras", 2009. [Online]. Disponible en: http://www. invias. gov.co/

[9] RAS, "Título D: Sistemas de recolección y evacuación de aguas residuales domésticas y pluviales", 2000. [Online]. Disponible en: http:// www.minvivienda.gov.co/viceministerios/ viceministerio-de-agua/

[10] O. Mesa and B. Botero, "Errores detectados al estimar escorrentía directa, mediante algunos métodos de hidrogramas unitarios sintéticos", Avances en Recursos Hidráulicos, vol. 1, no. 8, pp. 27-38, 2001.

[11] M. Vélez, W. Quintero and J. Delgado, "Implementación del Modelo MG para Antioquia y el Eje Cafetero", Avances en Recursos Hidráulicos, vol. 1, no. 14, pp. 87-99, 2006.

[12] P. Acosta and C. Caro, "Regionalización de parámetros hidrológicos. Aplicación para intensidad media de precipitación”, V Congreso Internacional de Ingeniería civil, Universidad Santo Tomás, Tunja, 2014.

[13] G. Poveda and D. M. Álvarez, "El colapso de la hipótesis de estacionariedad por cambio y variabilidad climática: implicaciones para el diseño hidrológico en ingeniería", Revista de Ingeniería, vol. 1, no. 14, pp. 65-76, 2012. 